\title{
Ushering Towards an Era of Positive Diplomacy: The Reunification of the Korean Peninsula
}

\author{
Preethi Amaresh
}

\begin{abstract}
The present détente between South and North Korea moving towards a new era for unification signifies a positive turn in International Relations. The two countries have been divided on the 38th parallel line since the 1950s and have chosen to move towards peace. This reminds one of the visions of the Berlin wall falling, families reuniting and armies being disbanded. With the recent "Winter Olympics", both the countries have marched together for a peaceful unification. Students from universities in Seoul and Pyongyang are preparing to spend time at each other's universities. There have also been talks about reopening railway links across the peninsula.

Today's peace efforts are undoubtedly better than the war mongering that occurred all these years. Though both of them have called for "Peace", the South compared to the North has become a major economic power with vibrant democracy and the later still remains isolated, impoverished country under the Kim family dynasty with little freedom for the citizens. The two Koreas haven't yet signed a peace deal to put an end to the conflict and have yet to officially recognize each other. In the past, some South Korean leaders have predicated their reunification plans on the assumption that North Korea's authoritarian regime would collapse and be absorbed by the South.

There are more than 30,000 North Korean refugees who are currently living in South Korea where many organizations are supporting and advocating an improvement in Human Rights in North Korea. The number of those making successful escapes to South Korea, via China has steadily also declined over the past few years. This can also mean that there may be a positive viewpoint in the relationship between the fall in numbers and the peace efforts where some North Koreans still hope that the life in the country would improve.

Some of the complications are that both Koreas have enshrined reunification in their constitutions where North Korea has described it as the nations supreme task and both have their own ministry and committee respectively for reunification. North Korea's founding leader, Kim II Sung in 1993 proposed a 10point program for reunification that includes a proposal for leaving the two systems and government intact and opening the borders.

Despite all the odds and complications both the Koreas after the reunification need to work together in establishing peace. South Korea should also recognize the genuine partnership of North Korea and the intellectual resources they have. Jobs, benefits and also education programs should be provided to them. Non Government Organizations (NGO's) can play a huge role in this process too. On whole, the unification should be based on 3 aspects: Liberal democracy, free market economy and a peninsula free of nuclear weapons. With respect to the liberal democracy, it would be up to the Korean people to decide that through a constitutional process.
\end{abstract}

Preethi Amaresh, Research Associate (International Relations), Aram Institute for Indian Civil Services, India.
Keywords - Era of Positive Diplomacy, Reunification.

\section{KOREAN PENINSULA-HISTORY}

Korean Peninsula has been one of the most potentially volatile and dangerous regions since World War 2 and at the same time South Korea made tremendous progress under the American shadow. In the process while North Korea became a dictatorship and a rogue state and part of the "Axis of Evil", the South Koreans turned into a vibrant democracy, model of economic miracle an OECD economy and a close partner of west. Seoul even has US troops based for decades to protect it from any regional mishap. The two Koreas have occasionally tried to bridge their differences towards reunification but the US, Russia and Chinese factor and the mistrust kept them at loggerheads for over 5 decades. North Korea has a chequered History especially with regard to its neighbors be it Japan, South Korea along the USA or the support from erstwhile Soviet Union and Communist China, which crafted its balancing act.

The Korean History is replete with wars, invasions, colonization yet securing and retaining its cultural identity and proud history from the $18 \mathrm{BC}$ onwards at least until 10th century $\mathrm{AD}$, when the peninsula encompassed the three kingdoms of Silla, Baekje and Goguryeo that covered the present day North and South Korea as well as Manchuria with Pyongyang as its capital.

The ensuing cold war between the USA and Soviet Union sealed the fate of unification until now although initial arrangement or trusteeship called in international parlance was to be for a period of 5 years. It was agreed at the Moscow conference where after elections were to be conducted and independence and independence of unified Korea was to be ensured. But the cold war and conflict between Communism and Capitalism and democracy and the race for more geographic strategic space dictated the status quo. The greater mistrust and animosity between the two Koreas was seeded and rest is history and that too a lot bitter with larger conflict and power grab between the two super powers and later China backing the north.

Consequently, UN declared Republic of South Korea as the only legitimate and lawful government of Korea on December 12, 1948. It was only in August 1991 that DPRK was admitted to the UN. There was a public furore and and discontent on both sides. However, on both sides of the 38th parallel a deep desire for unification or at least normalization of relations and free movement persists. 


\section{REUNIFICATION EFFORTS}

Efforts have also been made and several initiatives to neutralize the hostility was introduced. In 1969, President Park Chung Hee established National unification Board that was subsequently upgraded to a Ministry of Unification in Seoul. Apart from analyzing various trends with its northern brother it encourages dialogue, exchanges and politico- economic, military and humanitarian co-operation. It also focuses on POW's and abductees as well as reunion of separated families and supports dislocated North Koreans. More importantly it focuses a great deal on the denuclearization of the peninsula, which is the key to any peace efforts or solution to the ongoing problems. It also generates mutual trust through confidence building measures, as peace and togetherness will usher in prosperity for all the Korean people.

The Sunshine Policy, launched by president Kim Dae-Jung in 1998 was predicted on three basic principles; no forgiveness to DPRK for any military provocation or mis-adventure; non-absorption of North by any method; and injection of significant investments, aid and assistance to wean away north from its military pursuits and avoidable expenditure. He drew the analogy a great deal from the German unification. Hence the Kaesong Industrial Region was created in DPRK where north and south Koreans could work together which enhanced mutual trust and cultural and economic exchanges that were beneficial to both sides.

\section{USHERING PEACE IN THE PENINSULA}

South Korean president Moon Jae-in is an avid believer in the reunification and normalization of relations and has taken exceptional steps to achieve the objectives by acting as a key mediator and negotiator between themselves and DPRK and USA. Credit must also go to Kim Jong UN the North Korean leader for realizing the limitations of his enterprise and to move forward with the South and the US after displaying his firepower and defying the world and extensive sanctions.

Kim had continued to conduct missile tests including the ICBM and took it to American territory. Claimed to have developed nuclear fusion technology and Hydrogen bomb. The whole idea was to dismantle the NPT defiant Pyongyang to bring back its fold by disabling its nuclear programme through a "complete, verifiable and irreversible dismantlement of its nuclear facilities and programme. In return Pyongyang sought a non-aggression pact with the US and removal of sanctions. President Moon since 2017 has made several efforts and had Summits as well as informal meeting with his North Korean counterpart. Symbolic gestures were clearly evident especially when the two leaders for the first time stepped into one another's territory at DMZ holding hands. Sports diplomacy was at its peak when the two countries fielded unified teams at the winter games or table tennis tournaments.

North Korea is definitely looking for greater respect, international recognition and engagement for economic prosperity. Director General presented the "New Economic Map Initiative" for Inter-Korean Exchange and Cooperation Jee
Jootae of the Ministry of Unification at the Korea Global Forum 2018.

Seoul's plan calls for phased implementation and active cooperation with regional economies- China, Russia and Japan. It also syncs with North Korea's economic objectives, based around its 2016- 2020 five-year plan, its 26 special economic zones and its plans to realize socialism.

The South Korean master plan is based around three "economic belts". The first on the west of the peninsula, the "Yellow Sea Industry/ Logistics Belt," would create industrial cooperation in special economic zones, linked by a north-south logistics net of road and rail lines running through the key cities of Seoul, Pyongyang and Shinuiju on the North Korea - China border and then into China. The second on the more rugged eastern side of the peninsula, the "Pan-East Sea Energy/Resource Belt", would build infrastructure - LNG pipelines and rail lines- Linking both Koreas to the Russian Far East. The third, the DMZ peace belt", across the waist of the peninsula, calls for converting the underdeveloped, 4 kilometer wide demilitarized zone into cooperative space for ecological, environmental and tourist development. It would also include a "Maritime Peace Zone" to obviate naval clashes. The whole idea is to create single economic zone by assimilating the economic and institutional diversities of the two sides. Finally Kim and Moon signed the Panmunjom Declaration that provided the much needed hope and agreed framework at the highest level to normalize the situation.

The love-hate dynamic started during Trump's candidacy in 2015, when he described Mr. Kim as "this maniac sitting there" with nuclear weapons who had to be dealt with. Once Mr. Trump became the president, the insults continued. But by June 2018 things had changed when Trump not only met KIM but also called him an "Honorable Man" and expressed a great hope. The most realistic view would be for US to have a capacity to accommodate North Korea into the international community as a nuclear state with guarantee that its security remains guaranteed. There seems to be no better alternative than this at the moment.

North Korea has a track record of using denuclearization talks to extract aid and other concessions, while covertly continuing development of nuclear weapons and ballistic missiles. Pyongyang's decision to return some of the remains of American troops who died in the 1950-53 conflict, and starting to dismantle a missile engine testing site are seen as cosmetic..

\section{CONCLUSION}

Sanctions imposed by the UNSC since 2006 following the nuclear tests have continued intermittently hobbling North Korea's integration with the rest of the world. North Korea is revealed to be a dark country by satellites unlike the glowing lights of South Korea. Despite this 'darkness', North Korea exports electricity to China worth a couple of million dollars every year. North Korea has increased it trade with Russia even as China slowly reduces its singular dominance on trade issues with Pyongyang.

A nation with potential is yet stuck in a time wrap of ideology 
and a historical frame strangely immune to accept change and its welcoming notes.

Pooling of the resources of the two Koreas, like technology and the rare minerals could make them into a bigger industrial giant and an economic power with a commensurate manufacturing hub comparable to China or Japan. The Singapore declaration has created political space for engaging in the dialogue amidst a situation when relation between US and North Korea was at its worst.

Fortunately, both Washington and Pyongyang are moving exactly in the expected direction and their present mutual understanding and coming togetherness, if the pace continues may prove to be a landmark in the History of International Relations

\section{REFERENCES}

[1] Jonnson Gabriel, South Korea in the United Nations, (https://books.google.co.in/books?id=bwGuDgAAQBAJ\&pg=PA25\&lp $\mathrm{g}=\mathrm{PA} 25 \& \mathrm{dq}=\mathrm{UN}+$ declared+Republic + of + South + Korea $+\mathrm{as}+$ the + only +1 egitimate+and+lawful+government+of+Korea+on+December+12,+194 8.+It+was+only+in+August+1991+that+DPRK+was+admitted+to+the+ $\mathrm{UN \&}$ source=bl\&ots=jNJkcIn2gL\&sig=shFWBPAQxS5tD1oPveP2UQ8 HxMY\&hl=en\&sa=X\&ved=2ahUKEwj137aUlbDeAhWKV7 $w K H e 5 w$ DR8Q6AEwDnoECAMQAQ\#v=onepage $\& \mathrm{q}=\mathrm{UN} \%$ 20declared\%20Rep ublic $\% 20$ of $\% 20$ South $\% 20$ Korea\%20as\%20the $\% 20$ only\%20legitimate $\% 20$ and $\% 20$ lawful $\% 20$ government $\% 20$ of $\% 20$ Korea $\% 20$ on $\% 20$ Decem ber\%2012\%2C\%201948.\%20It\%20was\%20only\%20in\%20August $\% 20$ $1991 \% 20$ that\%20DPRK\%20was\%20admitted\%20to\%20the\%20UN\&f =false)

[2] ${ }^{1}$ Yang Chang Seok, The North Korea Instability project, 2016 (https://www.38north.org/wp-content/uploads/2016/12/NKIP-Yang-Ger man-Reunification.pdf)

[3] ${ }^{1}$ Jesse Min, The Sunshine Policy of North Korea, 2017, Stanford University, (http://large.stanford.edu/courses/2017/ph241/min2/)

[4] ${ }^{1}$ Sports diplomacy in Korean peninsula, International Crisis Group, February 8, 2018, (https://www.crisisgroup.org/asia/north-east-asia/korean-peninsula/sport s-diplomacy-korean-peninsula)

[5] ${ }^{1}$ New Economic Map for the Korean Peninsula and Regional Cooperation in Northeast Asia: Establishment of Peace and Economic Growth, Ministry of Unification, December 2017 (https://www.unikorea.go.kr/eng_unikorea/news/speeches/?boardId=bbs _0000000000000036\&mode=view \&cntId=54115\&category=\&pageIdx $=)$

[6] ${ }^{1}$ S Korea unveils plan for N Korean economic enrichment, Andrew $\begin{array}{llll}\text { Salmon, July } & 3, & 318\end{array}$ (http://www.atimes.com/article/sth-korea-unveils-plan-for-north-koreaneconomic-enrichment/). 